Article

\title{
Prey-Related Asphyxiation in Harbor Porpoises (Phocoena phocoena) along the U.S. West Coast: Importance of American Shad (Alosa sapidissima) on Adult Female Harbor Porpoise Mortality
}

\author{
Cindy R. Elliser ${ }^{1, *}$, John Calambokidis ${ }^{2}$, Dalin N. D'Alessandro ${ }^{3}$, Deborah A. Duffield ${ }^{3}$, \\ Jessica L. Huggins ${ }^{2}$, James Rice ${ }^{4}$, Isidore Szczepaniak ${ }^{5,6}$ and Marc Webber 5,6 \\ 1 Pacific Mammal Research, Anacortes, WA 98221, USA \\ 2 Cascadia Research Collective, Olympia, WA 98501, USA; Calambokidis@cascadiaresearch.org (J.C.); \\ JHuggins@cascadiaresearch.org (J.L.H.) \\ 3 Department of Biology, Portland State University, Portland, OR 97207, USA; dalin@pdx.edu (D.N.D.); \\ duffieldd@pdx.edu (D.A.D.) \\ 4 Marine Mammal Institute, Oregon State University, Newport, OR 97365, USA; Jim.Rice@oregonstate.edu \\ 5 The Marine Mammal Center, Sausalito, CA 94965, USA; szczepaniaki@tmmc.org (I.S.); \\ webberm@tmmc.org (M.W.) \\ 6 Department of Ornithology and Mammalogy, California Academy of Sciences, San Francisco, CA 94118, USA \\ * Correspondence: cindy.elliser@pacmam.org
}

Received: 2 May 2020; Accepted: 23 June 2020; Published: 29 June 2020

\begin{abstract}
Harbor porpoise (Phocoena phocoena) diets are predominantly comprised of small fish species $(<30 \mathrm{~cm}$ ) and squid. However, predation on larger species (up to $63 \mathrm{~cm}$ ) occurs, raising the question of increased risk of asphyxiation associated with this behavior. Literature was reviewed and stranding data from 1983 to 2020 from the U.S. West Coast (including California, Oregon and Washington) were searched for cases of prey-related asphyxiation of harbor porpoises and analyzed in relation to age, sex, reproductive status and prey species. Twenty-nine cases were documented. Twenty-seven cases involved large prey; non-native American shad caused the asphyxiation in $87 \%$ of the cases where the prey species was identified. The majority $(92 \%)$ of harbor porpoises were females, and at least $83.3 \%$ were pregnant or recently post-partum. Reproductively active females may be more likely to attempt potentially risky behavior in order to compensate for their increased energetic needs. Increasing numbers of non-native American shad may pose a unique danger in this region for harbor porpoises not adapted to deal with the challenges of that prey. This may be a cause for concern, as there is likely an interaction between location, age and reproductive status on the diet composition and foraging strategies of harbor porpoises.
\end{abstract}

Keywords: harbor porpoise; Phocoena phocoena; American shad; salmon; asphyxiation; large prey; foraging ecology; strandings

\section{Introduction}

Harbor porpoises (Phocoena phocoena) are found in nearshore waters along the U.S. West Coast from north of Point Barrow, Alaska (AK), and south to Point Conception, California (CA) [1-3], with very few sightings in offshore waters (beyond the $200 \mathrm{~m}$ isobath) [3]. It is important to note that along the U.S. West Coast, the continental shelf is narrow (approximately $32 \mathrm{~km}$ ) compared to locations in the Atlantic (more than $120 \mathrm{~km}$ ) [4]. Thus, harbor porpoises on the U.S. West Coast are a nearshore species, unlike some harbor porpoises that are seen in offshore waters in the Atlantic (e.g., off Greenland [5]). Along 
the U.S. West Coast, harbor porpoises are known to mainly prey on small fish species, such as Pacific herring (Clupea pallasi), walleye pollock (Theragra chalcogramma), Pacific hake (Merluccius productus) northern anchovy (Engraulis mordax) and Pacific sandlance (Ammodytes hexapterus), that average less than $30 \mathrm{~cm}$ in length [6-12], a similar finding to other populations worldwide [13-23].

Harbor porpoises have also been known to ingest large (in mass and/or length, e.g., up to $63 \mathrm{~cm}$ ) prey items $[16,17,21,22,24]$. Along the U.S. West Coast, harbor porpoises were observed catching large prey items (consumption was not observed) of native salmonid species, including coho (Oncorhynchus kisutch) and pink (Oncorhynchus gorbuscha) salmon, and non-native American shad (Alosa sapidissima) [25]. A recent study documented tags from juvenile Chinook salmon (Oncorhynchus tshawytscha) in the forestomach of a harbor porpoise in southwestern Washington [26]. Previous to these cases, there were rare instances of salmon in the stomachs of harbor porpoises in this region: a salmon sp. in the stomach of a stranded harbor porpoise near the Columbia River [27] and another of a coho salmon in the stomach of a by-caught harbor porpoise in the salmon set-net fishery in Washington State [8]. Salmon have not been considered as part of the normal harbor porpoise diet in this region, but [25] supports the idea presented by [26] that salmon may be a more important component of harbor porpoise diet in the Pacific Northwest than previously thought. Occasionally, attempted ingestion of seemingly atypical prey items and/or prey size that resulted in asphyxiation of the harbor porpoise have been documented along the U.S. West Coast: $55.9 \mathrm{~cm}$ grey smooth-hound shark (Mustelus californicus [28]), $44.5 \mathrm{~cm}$ Pacific herring [29], American shad (37.5 cm, [30] and $34.2 \mathrm{~cm}$ [31]) and a species of sculpin [32]. The historical asphyxiation records of female harbor porpoises [30,31] and more recent observations of live female harbor porpoises [25] indicate that American shad may be targeted by some individuals, and there may be a female sex bias to this potentially risky behavior.

Large prey (like salmon and American shad) can increase the risk of asphyxiation in odontocete species due to adaptations to their airway and digestive tracts that removes the risk of water accidentally entering the respiratory system during ingestion of prey [33]. While important, these adaptations also make them more susceptible to esophageal obstruction that can lead to asphyxiation as the larynx, or goosebeak, creates a restriction, limiting the size of items that can be swallowed without risk of them becoming lodged around the larynx (which may become dislocated) [33]. Though not a common occurrence, cause of death by asphyxiation on prey items has been documented in a limited number of cetacean species (harbor porpoises [19,28,30-32,34-37], bottlenose dolphins (Tursiops sp.) [38-42], long-finned pilot whales (Globicephala melas) [43], Guiana dolphins (Sotalia guianensis) [44], and beluga whales (Delphinapterus leucas) [45]).

Much of what is known about harbor porpoises in the Pacific Northwest comes from stranded animals [46], as harbor porpoise behavior is still poorly understood and often hard to investigate due to their elusive nature. Stranding records are a good resource for investigating causes of death and their frequency within a population and can provide insights into harbor porpoise foraging behavior. American shad in the Pacific Ocean are mainly found on the continental shelf, with the highest catches (based on data from research cruises, and commercial and recreational landings) between Oregon (OR) and British Columbia (BC), Canada, and in San Francisco Bay [47]. To investigate the occurrence of prey-related asphyxiation in harbor porpoises along the U.S. West Coast and the influence of American shad, we reviewed the available stranding records from researchers and stranding organizations in CA, OR and WA, along with historical published accounts; however, note that this was not an exhaustive search of all historical records. To enhance our knowledge of harbor porpoise foraging behavior we describe these cases, the fish species involved, and the relation to age, sex and reproductive status of the harbor porpoises. We hypothesized that the majority of harbor porpoise asphyxiation cases would involve non-native American shad, and that asphyxiation would occur more with reproductively active females than other age/sex classes. 


\section{Materials and Methods}

Necropsies and records of the stranded harbor porpoises were conducted/recorded by individual researchers and stranding network organizations along the U.S. West Coast (Figure 1): Cascadia Research Collective (CRC), Portland State University (PSU), Oregon State University (OSU), Washington Department of Fish and Wildlife (WDFW) the California Academy of Sciences (CAS), The Marine Mammal Center (TMMC), California State Parks (CSP), and the Museum of Vertebrate Zoology (MVZ). Although there may be some variation in specifics, the organizations generally adhered to similar stranding and necropsy protocols. Data including the date, location, condition, age class, sex, reproductive status, and evidence of human interaction were collected from all stranding events. Necropsies were conducted on fresh animals using established methods [48]. A full suite of samples from available organs, lymph nodes, lesions and injuries were collected for histology, and additional tissues were frozen for ancillary diagnostics (genetics, contaminants, life history, biotoxins, fungal, viral, bacterial screening). Visual identification of stomach contents was documented for some cases. Internal exams with minimal sampling were conducted on animals that were decomposed and/or heavily scavenged. Evidence for human interaction (vessel interaction, gunshot wounds, fishery interaction wounds related to fishing gear or fishing gear attached to the animal, and other) was noted, whether or not it was the cause of death.

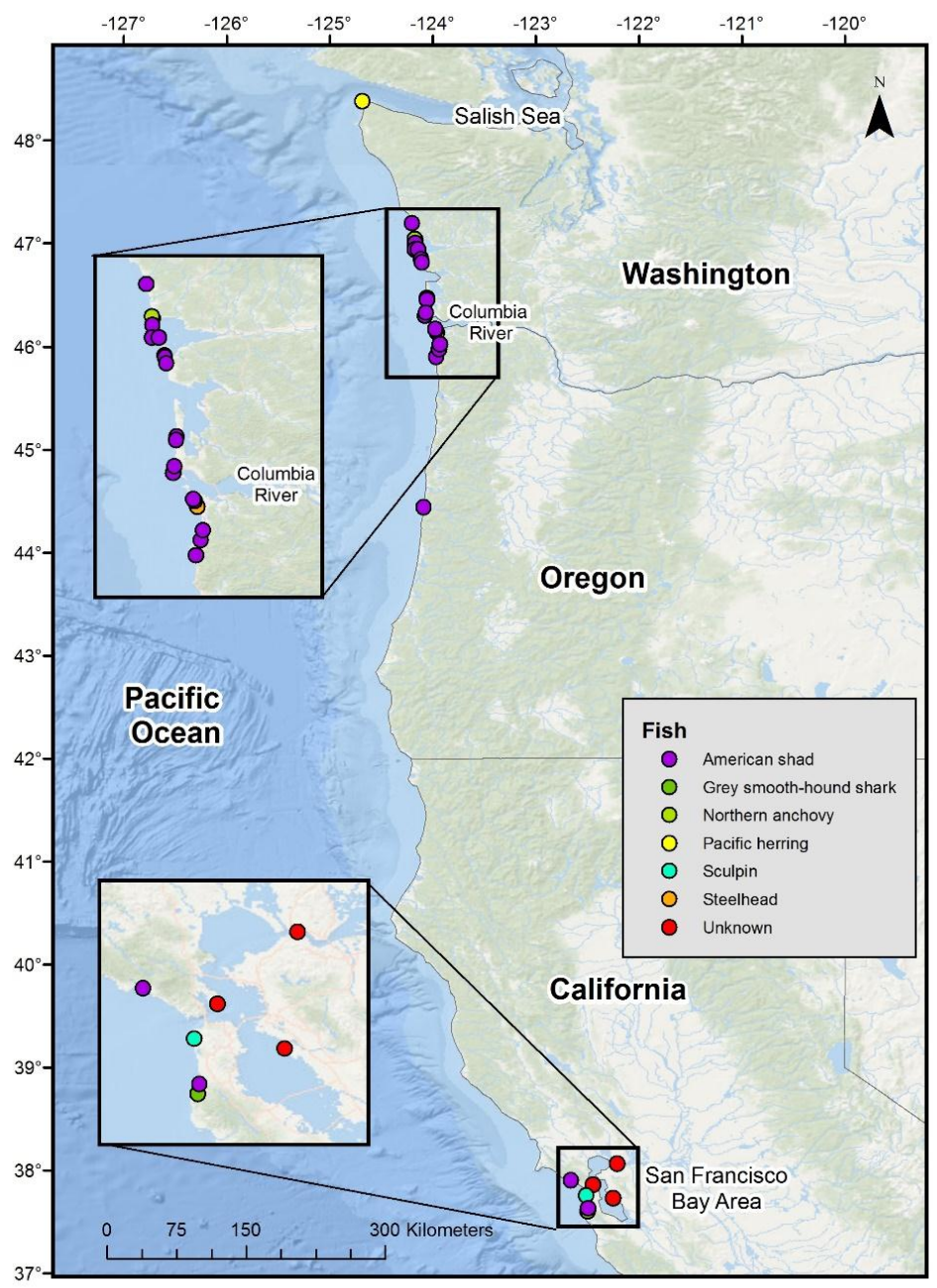

Figure 1. Map of U.S. West Coast with locations (and fish species involved) of asphyxiation cases of harbor porpoises in CA, OR and WA. 


\section{Results}

We documented 24 cases between 1983 and 2020 (numerical case numbers 1-24) from stranding records, in addition to 5 cases previously published (alphabetic case numbers A-E), totaling 29 cases of fatal prey-related asphyxiation in harbor porpoises along the U.S. West Coast since 1937 (Figure 1, Table 1). For the 28 cases where the month and day of stranding are known (all but case B), asphyxiated harbor porpoises were found in every month except November, and $13(46.4 \%)$ of these occurred in spring (March-May). The next most common season was summer (June-August) with eight (28.6\%) cases. The number of cases in other seasons were more evenly distributed: three (10.7\%) in winter (December-February), and four (14.3\%) in fall (September-November). Five cases (10, 15-18) also had evidence of fishery interaction and eight $(4,6,8,11,15,16,19,24)$ had pathological findings. The contribution of these additional findings to the asphyxiation events are not known. Visual identification of stomach contents for five cases were documented. Case 2 had a pilchard (Sardinops sagax) and squid beaks (Loligo sp.), case 13 had squid beaks and fresh anchovy, case 18 had an intact American shad, case 21 had fresh and partially digested anchovy and case 24 had partially digested anchovy.

Two types of asphyxiation were found: large fish lodged in the throat, where the goosebeak is often dislocated (cases A-D, 1-20, 22-24), and smaller fish moving up to obstruct the nasal passage (cases E, 21). Twenty-seven cases (93.1\%) resulted from attempted ingestion of large prey items and subsequent asphyxiation (cases A-D, 1-20, 22-24); 25 were confirmed as cause of death and 2 where it was the likely cause of death, but the carcass was not collected (cases 5, 9, Table 1). Many of these incidences occurred in the last four years $(n=9,33 \%)$. In all cases the large fish was lodged in the harbor porpoise's throat, sometimes with the tail still visibly sticking out of the mouth (Figures 2, 3, 5 and 6). The fish was known to be oriented head first in all but two cases $(92.6 \%$, in cases D and 9 the orientation was not documented). In 18 (66.7\%) cases the larynx or goosebeak was dislocated (Figure 2), sometimes with the fish extending past the proximal end of the lungs. Dry drowning was suspected in the four cases $(13,21,22,24)$ for which the condition of the lungs was noted. Observations included very aerated lung tissue, white stable froth in main airways and trachea and no fluid, with the exception of one case (22) that had a small amount of fluid at the base of one lung.

American shad was the species causing the asphyxiation in $87 \%(n=20$, cases B-C, $1-4,6,8,10-15$, $17-19,22-24)$ of the large prey ingestion cases where the prey species was identified. The American shad ranged in length from 33 to $49 \mathrm{~cm}$ ( $\mathrm{n}=18$ cases where the whole fish was measured) and weighed from 363 to $1269 \mathrm{~g}$ ( $\mathrm{n}=10$ cases where the whole fish was weighed). The other identified large fish species was a steelhead (Oncorhynchus mykiss; $70 \mathrm{~cm}, 3200 \mathrm{~g}$, case 16), grey smooth-hound shark (55.9 cm, case A), Pacific herring (44.5 cm, case D) and four unknown species (cases 5, 7, 9, 20). For the cases involving large prey items and known sex of the harbor porpoise $(n=25), 23$ were female $(92 \%$, cases A-D , 1-4, 6, 8, 11-20, 22-24) and 2 were male $(8 \%$, cases 7,10$)$. Size of the female harbor porpoises ranged from 101.6 to $181 \mathrm{~cm}$, and males (both subadult) were 121.7 and $130 \mathrm{~cm}$ in size (Table 1). Reproductive status was determined for 18 females that attempted to ingest the large prey items: $11.1 \%(n=2)$ were not pregnant (cases $C, 14)$ and $66.7 \%(n=12)$ were confirmed to be pregnant (cases D, 4, 6, 8, 11-13, 15-16, 18-19, 24). Four other cases were likely recently pregnant: one with endometrial hemosiderosis suggestive of recent prior pregnancy (case 3), one with a distended uterus (case 17), one possibly post-partum (case 22) and one with a recent corpus luteum (case 23) (Table 1). Combining the 12 pregnancies with three likely post-partum females raises the percentage of cases of reproductively active females to $83.3 \%(n=15)$, or $88.9 \%(n=16)$ if the female with a recent corpus luteum is included. 
Table 1. Cases of prey-related asphyxiation of harbor porpoises including life history characteristics, fish species (size and weight when available) and details of the necropsy findings along the U.S. West Coast. * Cases A-E are previously published accounts [28-32]. For large prey items, the fish was stuck head first in all but two cases (D and 9), where the orientation was not documented.

\begin{tabular}{|c|c|c|c|c|c|c|c|c|c|c|c|c|}
\hline Case & $\begin{array}{c}\text { Date } \\
\text { (Year/Month/Day) }\end{array}$ & State & Contributor & HP Sex & HP Age & $\begin{array}{l}\text { Length } \\
(\mathrm{cm})\end{array}$ & $\begin{array}{l}\text { Carcass } \\
\text { Condition }\end{array}$ & $\begin{array}{l}\text { PReproductive } \\
\text { Status }\end{array}$ & Fish Species & $\begin{array}{l}\text { Fish Length } \\
(\mathrm{cm})\end{array}$ & $\begin{array}{c}\text { Fish } \\
\text { Weight (g) }\end{array}$ & Details \\
\hline A & 1937/3/9 & CA & $28^{*}$ & $\mathrm{~F}$ & SubA & 101.6 & Fresh & Unknown & $\begin{array}{l}\text { Grey smooth-hound } \\
\text { shark }\end{array}$ & 55.9 & NA & $\begin{array}{l}\text { Tail of the shark was sticking out of mouth, head was partly } \\
\text { in stomach. Froth in lung indicated suffocation. }\end{array}$ \\
\hline B & 1948 & WA & $30^{*}$ & $\mathrm{~F}$ & A & Unknown & Unknown & Unknown & American shad & 37.5 & $\mathrm{NA}$ & American shad stuck head first in throat. \\
\hline C & $1952 / 6 / 8$ & WA & 31 * & $\mathrm{F}$ & A & 147 & Fresh & $\begin{array}{c}\text { Not visibly } \\
\text { pregnant }\end{array}$ & American shad & 34.2 & 680 & American shad stuck head first in throat. \\
\hline D & 1979/12/19 & WA & $29 *$ & $\mathrm{~F}$ & A & 137 & Fresh & Pregnant & Pacific herring & 44.5 & NA & $\begin{array}{l}\text { Fish firmly stuck in throat, pregnant with } 20.3 \mathrm{~cm} \text { well } \\
\text { developed fetus. }\end{array}$ \\
\hline $\mathrm{E}$ & 2008/6/30 & $\mathrm{CA}$ & $32 *$ & $\mathrm{M}$ & SubA & 132 & Fresh & NA & Sculpin sp. & $\sim 13$ & NA & Sculpin lodged in nasal passages, completely obstructing it. \\
\hline 1 & $1983 / 5 / 9$ & WA & WDFW & $\mathrm{F}$ & A & 150 & Moderate & Unknown & American shad & NA & NA & $\begin{array}{l}\text { American shad stuck in throat with tail sticking out of the } \\
\text { mouth. }\end{array}$ \\
\hline 2 & 1992/9/5 & $\mathrm{CA}$ & CAS/MVZ & $\mathrm{F}$ & A & 153 & Moderate & Unknown & American shad & NA & NA & $\begin{array}{l}\text { American shad stuck in throat with tail sticking out of the } \\
\text { mouth; A pilchard and several squid beaks in stomach. }\end{array}$ \\
\hline 3 & 2005/6/19 & $\mathrm{CA}$ & TMMC & $\mathrm{F}$ & A & 165 & Fair & $\begin{array}{l}\text { Recently pregnant, } \\
\text { endometrial } \\
\text { hemosiderosis }\end{array}$ & American shad & 41 & NA & $\begin{array}{l}\text { American shad wedged in esophagus, tail was sticking out } \\
\text { of the mouth, goosebeak was dislocated. }\end{array}$ \\
\hline 4 & 2006/1/12 & WA & CRC & $\mathrm{F}$ & A & 161 & Fresh & Pregnant & American shad & NA & NA & $\begin{array}{l}\text { American shad stuck in throat head first, goosebeak } \\
\text { dislocated. }\end{array}$ \\
\hline 5 & $2007 / 5 / 5$ & WA & CRC & U & A & 150 (est.) & Fresh & Unknown & Unknown large fish & NA & NA & $\begin{array}{l}\text { Large fish was lodged in mouth, only the tail was visible. } \\
\text { Reported by reliable source, carcass not collected. }\end{array}$ \\
\hline 6 & 2008/5/21 & OR & PSU & $\mathrm{F}$ & A & 162.5 & Moderate & Pregnant & American shad & 47 & 943 & $\begin{array}{l}\text { American shad stuck head first in throat, goosebeak } \\
\text { dislocated. }\end{array}$ \\
\hline 7 & $2009 / 3 / 6$ & $\mathrm{CA}$ & CAS & M & SubA & 130 & Moderate & NA & Unknown large fish & 35 & NA & $\begin{array}{l}\text { Fish lodged in esophagus with tail extending into the oral } \\
\text { cavity, goosebeak dislocated and esophagus was distended. }\end{array}$ \\
\hline 8 & 2009/3/14 & OR & PSU & $\mathrm{F}$ & A & 151.4 & Moderate & Pregnant & American shad & 43 & 852 & $\begin{array}{l}\text { American shad stuck head first in throat, goosebeak } \\
\text { dislocated. }\end{array}$ \\
\hline 9 & 2010/6/1 & $\mathrm{CA}$ & CSP & $\mathrm{U}$ & SubA & 122 & Fresh & Unknown & Unknown large fish & NA & NA & Fish stuck in throat, carcass not collected. \\
\hline 10 & 2011/9/13 & WA & PSU & M & SubA & 121.7 & Moderate & NA & American shad & 33 & 398 & $\begin{array}{l}\text { American shad stuck head first in throat, goosebeak } \\
\text { dislocated, fishery interaction. }\end{array}$ \\
\hline 11 & 2013/4/29 & OR & OSU & F & A & 163 & Fresh & Pregnant & American shad & 38 & $\mathrm{NA}$ & $\begin{array}{l}\text { American shad stuck in throat head first obstructing the } \\
\text { trachea and bruising the goosebeak. }\end{array}$ \\
\hline 12 & 2014/2/1 & WA & PSU & $\mathrm{F}$ & A & 162.5 & Moderate & Pregnant & American shad & 42.5 & 755 & $\begin{array}{l}\text { American shad stuck head first in throat, goosebeak } \\
\text { dislocated. }\end{array}$ \\
\hline 13 & 2014/3/20 & WA & CRC & $\mathrm{F}$ & A & 162 & Fresh & Pregnant & American shad & 35.5 & NA & $\begin{array}{l}\text { American shad stuck head first in throat, goosebeak } \\
\text { dislocated. Head of fish was down level with the lungs, } \\
\text { some regurgitated food in the esophagus. Squid beaks and } \\
\text { fresh anchovy in stomach. Figure } 2 .\end{array}$ \\
\hline 14 & 2014/5/9 & WA & CRC & $\mathrm{F}$ & A & 181 & $\begin{array}{l}\text { Moderate/ } \\
\text { Advanced }\end{array}$ & Not pregnant & American shad & $40^{*}$ & NA & $\begin{array}{l}\text { American shad stuck head first in throat, goosebeak } \\
\text { dislocated. Minimal exam due to carcass condition. * } \\
\text { scavenged, estimated length. Figure } 3 \text {. }\end{array}$ \\
\hline
\end{tabular}


Table 1. Cont

\begin{tabular}{|c|c|c|c|c|c|c|c|c|c|c|c|c|}
\hline Case & $\begin{array}{c}\text { Date } \\
\text { (Year/Month/Day) }\end{array}$ & State & Contributor & HP Sex & HP Age & $\begin{array}{c}\text { Length } \\
(\mathrm{cm})\end{array}$ & $\begin{array}{c}\text { Carcass } \\
\text { Condition }\end{array}$ & $\begin{array}{l}\text { कReproductive } \\
\text { Status }\end{array}$ & Fish Species & $\begin{array}{c}\text { Fish Length } \\
(\mathrm{cm})\end{array}$ & $\begin{array}{c}\text { Fish } \\
\text { Weight (g) }\end{array}$ & Details \\
\hline 15 & $2016 / 5 / 23$ & OR & PSU & $\mathrm{F}$ & A & 168 & Moderate & Pregnant & American shad & 46.7 & 870 & $\begin{array}{l}\text { American shad stuck head first in throat, goosebeak } \\
\text { dislocated. Fishery interaction. }\end{array}$ \\
\hline 16 & $2016 / 7 / 3$ & $\mathrm{OR}$ & PSU & $\mathrm{F}$ & A & 163 & Fresh & Pregnant & Steelhead & 70 & 3200 & $\begin{array}{l}\text { Steelhead stuck head first in throat, goosebeak dislocated. } \\
\text { Fishery interaction. A full-term fetus was pressing on the } \\
\text { caudal end of the forestomach, preventing full expansion of } \\
\text { the stomach by } 2.5 \text { to } 5 \mathrm{~cm} \text { and thereby preventing the fish } \\
\text { from being completely swallowed. }\end{array}$ \\
\hline 17 & 2016/7/16 & $\mathrm{OR}$ & PSU & $\mathrm{F}$ & A & 169.2 & Advanced & $\begin{array}{l}\text { Recently pregnant, } \\
\text { distended uterus }\end{array}$ & American shad & 49 & 837 & $\begin{array}{l}\text { American shad stuck head first in throat, goosebeak } \\
\text { dislocated. Fishery interaction. Recently pregnant with } \\
\text { distended uterus. }\end{array}$ \\
\hline 18 & $2017 / 4 / 28$ & WA & PSU & $\mathrm{F}$ & A & 174.5 & Moderate & Pregnant & American shad & 30.9 & 870 & $\begin{array}{l}\text { 3/4 of American shad stuck head first in throat, goosebeak } \\
\text { dislocated. Fishery interaction; } 649 \mathrm{~g} \text { intact American shad } \\
\text { also in forestomach. }\end{array}$ \\
\hline 19 & $2018 / 5 / 31$ & WA & PSU & $\mathrm{F}$ & A & 166 & Fresh & Pregnant & American shad & 41.1 & 1269 & $\begin{array}{l}\text { American shad stuck head first in throat, goosebeak } \\
\text { dislocated. }\end{array}$ \\
\hline 20 & 2018/8/15 & $\mathrm{CA}$ & CAS & $\mathrm{F}$ & A & 152.5 & Advanced & Unknown & Unknown large fish & $\sim 30$ & NA & $\begin{array}{l}\text { Fish stuck head first in throat, tail sticking out of the mouth, } \\
\text { goosebeak dislocated. }\end{array}$ \\
\hline 21 & 2018/10/3 & WA & CRC & $\mathrm{F}$ & A & 184 & Fresh & $\begin{array}{l}\text { Unable to } \\
\text { determine }\end{array}$ & Northern anchovy & 7.6 & NA & $\begin{array}{l}\text { Fish lodged in blowhole. It was suspected that the harbor } \\
\text { porpoise was feeding on the anchovy when attacked. The } \\
\text { goosebeak was dislocated and there was bruising and } \\
\text { edema around the blowhole at the top of the head and } \\
\text { bruising in the back of the throat (Figure 4). There were } \\
\text { pre-mortem bite marks from a broadnose seven gill shark. } \\
\text { Reproductive status of the harbor porpoises was unknown } \\
\text { because the shark had bitten out that area of the abdomen. } \\
\text { Fresh and partially digested anchovy in stomach. }\end{array}$ \\
\hline 22 & 2019/6/28 & WA & CRC & $\mathrm{F}$ & A & 174.5 & Fresh & $\begin{array}{c}\text { Possibly } \\
\text { post-partum }\end{array}$ & American shad & 49 & NA & $\begin{array}{l}\text { American shad stuck head first in throat, goosebeak } \\
\text { dislocated and the fish was down the esophagus past the } \\
\text { heart (Figure 5). Shad was a gravid female. }\end{array}$ \\
\hline 23 & 2019/9/19 & $\mathrm{OR}$ & PSU & $\mathrm{F}$ & A & 167.5 & Moderate & $\begin{array}{l}\text { Not pregnant, } \\
\text { recent corpus } \\
\text { luteum }\end{array}$ & American shad & 46.5 & 686 & $\begin{array}{l}\text { American shad stuck head first in throat, goosebeak } \\
\text { dislocated. Not pregnant or lactating, but had recent corpus } \\
\text { luteum. }\end{array}$ \\
\hline 24 & $2020 / 4 / 25$ & WA & CRC & $\mathrm{F}$ & A & 165 & Fresh & Pregnant & American shad & 49 & NA & $\begin{array}{l}\text { American shad (gravid female) stuck head first in throat, } \\
\text { goosebeak dislocated (Figure 6). Stomach full of partially } \\
\text { digested anchovy. Third-trimester fetus. }\end{array}$ \\
\hline
\end{tabular}


The last two asphyxiation cases resulted from a small fish species blocking the nasal passage. One case was the presumptive regurgitation, or pushed by force up the esophagus, of a northern anchovy (Engraulis mordax; $7.6 \mathrm{~cm}$, weight unknown, Figure 4), resulting from a shark attack from a probable broadnose seven gill shark (Notorynchus cepedianus). Determination of the shark species involved was based on the size and shape of bites, characteristics of the tooth marks on the skin, blubber and internal organs and the geographic location of the incident (case 21). The second was a species of sculpin $(\sim 13 \mathrm{~cm}$, weight unknown) that became lodged in the nasal passage (case E).
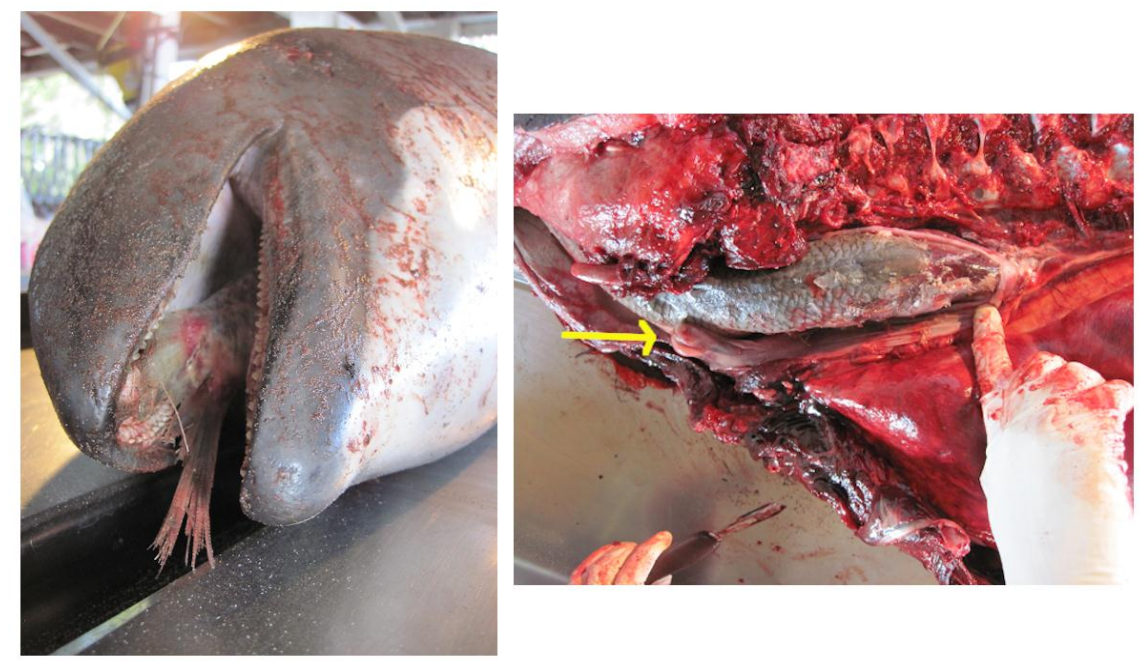

Figure 2. Case 13: 20 March 2014, pregnant adult female harbor porpoise from Ocean Shores, WA. American shad $(35.5 \mathrm{~cm}$ ) dislocated the goosebeak (arrow) from the blowhole area. Photo credit CRC.

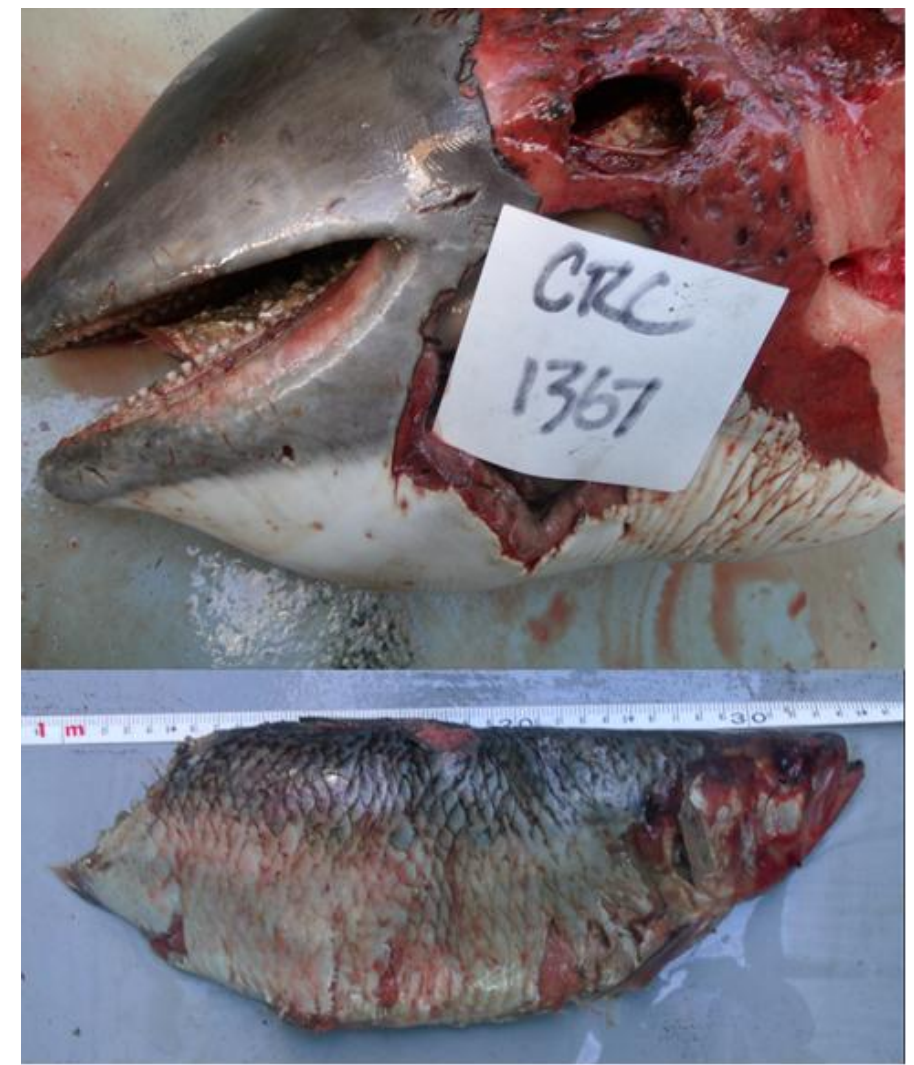

Figure 3. Case 14: 9 May 2014, American shad (partially eaten by scavengers post-mortem, estimated $40 \mathrm{~cm}$ ) that was found in an adult female harbor porpoise's throat causing asphyxiation (Westport, WA). Photo credit CRC. 


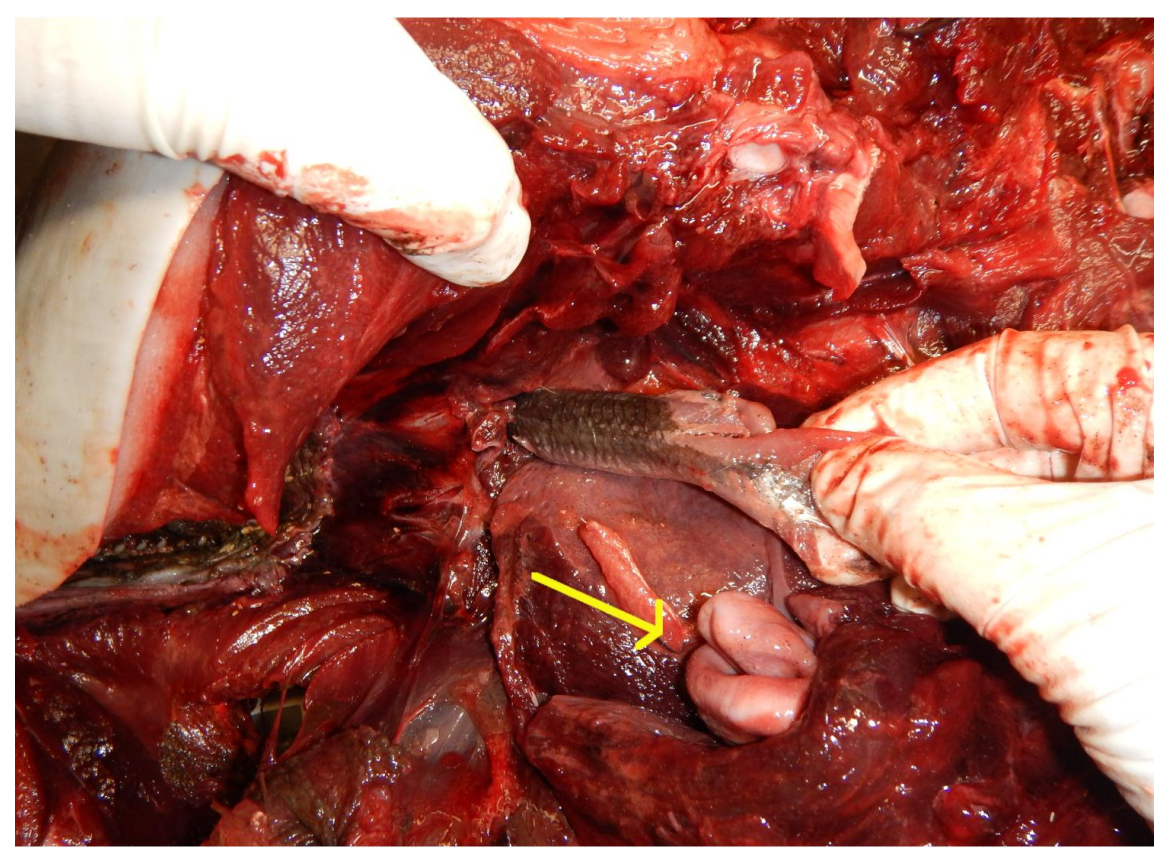

Figure 4. Case 21: October 3, 2018 adult female harbor porpoise from Ocean City, WA, asphyxiated on northern anchovy $(7.6 \mathrm{~cm}$ ) lodged in blowhole, goosebeak (arrow) dislocated with bruising and edema around the blowhole at the top of the head and bruising in the back of the throat. Photo credit CRC.

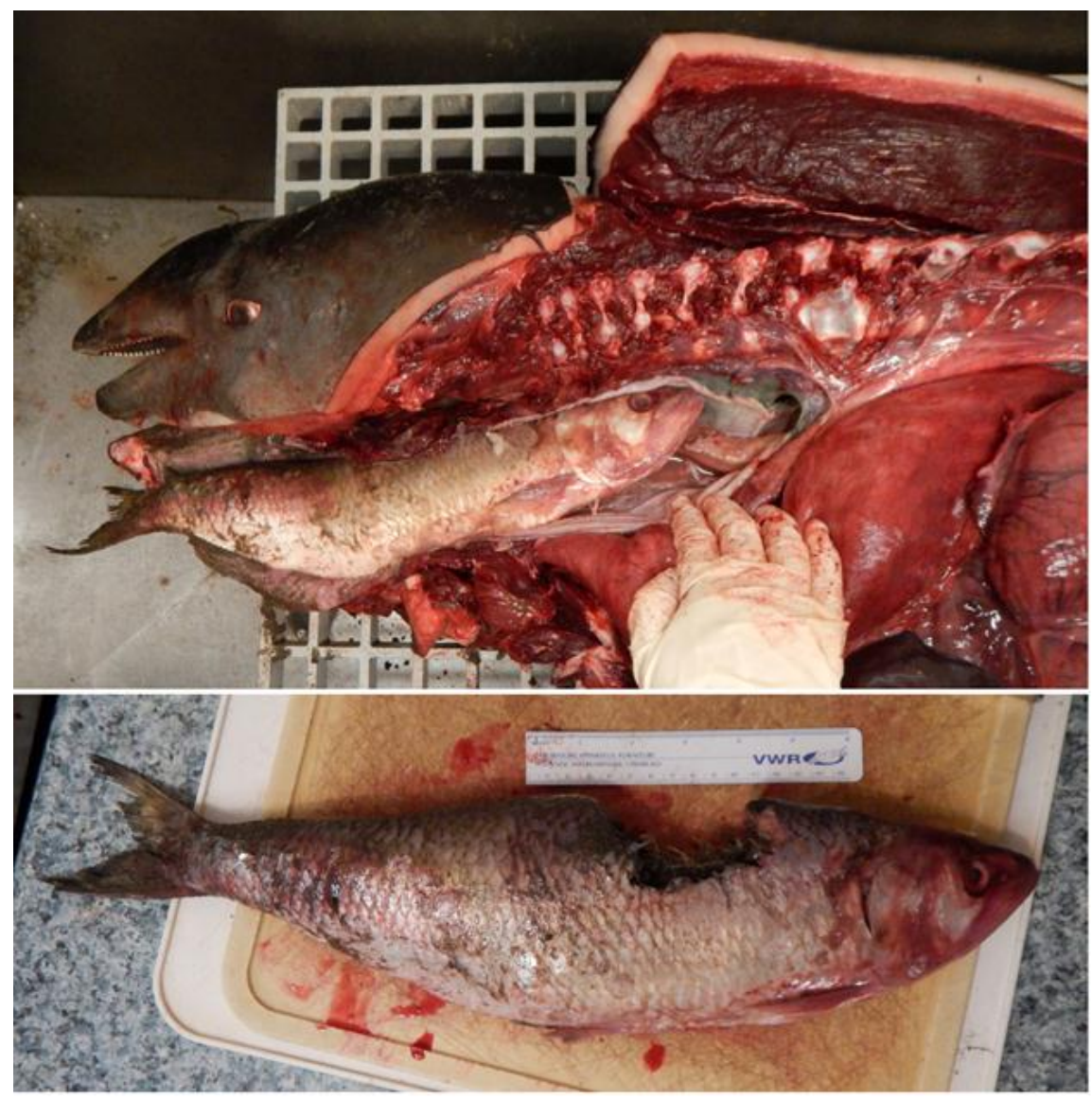

Figure 5. Case 22: 28 July 2019, possibly post-partum adult female harbor porpoise from Ocean Shores, WA, with $49 \mathrm{~cm}$ American shad stuck in in the throat (partially eaten by scavengers post-mortem), dislocating the goosebeak and stuck down the esophagus and past the heart. Photo credit CRC. 

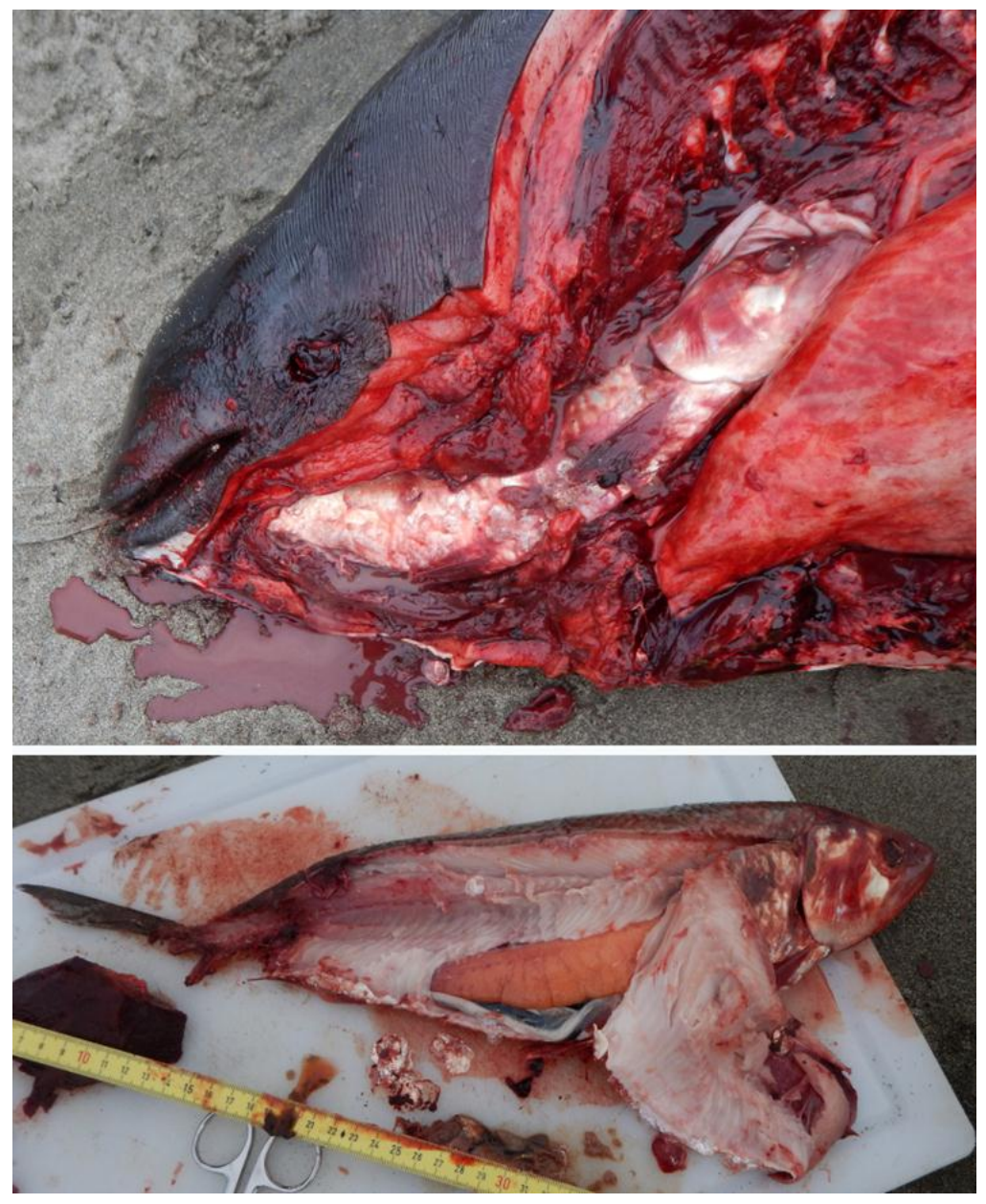

Figure 6. Case 24: 25 April 2020, third trimester pregnant adult female harbor porpoise from Ocean Shores, WA, with $49 \mathrm{~cm}$ American shad gravid female stuck in in the throat, dislocating the goosebeak.

\section{Discussion}

This study represents the largest set of records (29 total) published to date of prey-related asphyxiation in harbor porpoises. Of the large fish that were identified, $87 \%$ were American shad, showing a marked bias in the prey species responsible. These data support the idea that the events observed by [25] of harbor porpoises catching American shad and salmonid species along the U.S. West Coast were indeed foraging behavior, and that these species should be considered as potential prey species of harbor porpoise in this region. Further, our results suggest an age/sex bias to this behavior as $92 \%$ of harbor porpoises were female (all adult, except one), and that at least $83.3 \%$ of these females were in some stage of reproductive activity (pregnant or recently pregnant/post-partum). This bias towards females (and particularly pregnant females) is not reflected in overall stranding records for this region. In CA and the outer coast of WA, a total of 405 harbor porpoises were examined between 2005 and April 2020: 49.1\% male, 45.2\% female and 5.7\% unknown sex and in WA, 45.7\% of the adult females were pregnant (unpublished data). Although the cases of asphyxiation reported here represent a small portion of the total number of examined harbor porpoises, due to variability in carcass and environmental conditions, cetaceans that float or refloat and are cast ashore are likely a small subset of the actual mortality $[49,50]$ and additional instances may have occurred and have gone undetected. Thus, our results may underrepresent this source of mortality.

Harbor porpoises are the only cetaceans in the region with documented American shad asphyxiation, which may be the result of multiple factors. Since the introduction of American shad to the Pacific in the Sacramento River in 1871 (and now are found from Baja California, Mexico 
to Siberia) [51], these fish have overlapped in range with harbor porpoises as both are mainly found on the continental shelf, and consequently are more likely to interact with harbor porpoises than with cetaceans found in deeper water. The harbor porpoise preference for nearshore habitat also means that dead specimens of this species wash ashore more frequently, and in better post-mortem examination condition than offshore odontocetes [50]. Finally, as the world's second smallest cetacean, harbor porpoises may be ill-equipped to ingest American shad which averages 50-61.7 cm and up to $5500 \mathrm{~g}$ [52] simply due to predator-prey body size ratios and/or the morphology of American shad compared to other large prey items.

Remarkably, in nearly 40 years of diet studies, there is no evidence of American shad as prey for harbor porpoises along the U.S. West Coast based on otolith remains [6-9,11], stable isotope ratios [10] or PCR-based molecular techniques [12]. The rate at which otoliths erode varies by prey species [11] and American shad otoliths are relatively small, so this species may be more easily missed, or not recognized, in this type of diet study. Alternatively, the otoliths may not be present due to beheading the fish prior to consumption. Beheading and not ingesting the head of the fish has been suggested for harbor porpoises [13], and documented for rough-toothed dolphins (Steno bredanensis) [53], Amazon river dolphins (Inia geoffrensis) [54] and bottlenose dolphins [55]. However, this behavior has not been documented with American shad and the small spade-shaped teeth of harbor porpoises would make it difficult to perform the ripping or tearing action necessary to behead a large fish. In every case in the current study where the orientation of the fish was noted, the fish was head first down the harbor porpoise's throat. With the head hitting the gastric juices first, the head and the small otoliths may degrade quickly and thus not be present, or identifiable, when examined (a more likely scenario than beheading as suggested by [13]). Nevertheless, diet studies that do not rely on otolith remains have not found American shad in the diet of harbor porpoises in CA [10,12]. Alternatively, the lack of evidence of this prey species may be due to this being a more recent phenomenon, opportunistic captures, and/or that there are only certain groups or subpopulations (like reproductively active adult females in this study) that utilize this strategy (e.g., [55]).

In our study, $85.2 \%$ of the cases of asphyxiation on large prey items involved adult harbor porpoises. Variation in diet between adult and juvenile harbor porpoises has been reported [21,24]. A positive correlation between the length of harbor porpoises and some of their prey [21], along with the fact that adults are presumably more experienced foragers, make it more likely that adults would target larger prey than juveniles. However, if size was the only determinant (even with harbor porpoise females being marginally larger than males [56]), we would not see the striking bias towards females $(92 \%)$ that we documented. Other studies have shown a similar bias in sex and maturity influencing variation in harbor porpoise diet. In Icelandic waters, adult females had more diverse diets than males or subadult females, and two females (one pregnant) had ingested the largest prey items [21]. Other cases of asphyxiation are bias towards females (in the North Sea for common sole, Solea solea and cod, Gadus morhua (reproductive state not documented) [36]; in the Western Baltic, a lactating female likely asphyxiated (full necropsy was not completed) on a $59 \mathrm{~cm}$ European eel [37]). Together, these data suggest that adult female harbor porpoises may be more likely to target larger prey species and that this may be even further biased by reproductive state.

Over $83 \%$ of females of known reproductive state were either pregnant or recently pregnant/post-partum. With yearly or biyearly birth cycles [57,58], harbor porpoises spend much of their adult lives both pregnant and lactating $[59,60]$ and thus are likely to be in some stage of reproductive activity at any given time of year. Bioenergetic models (incorporating basal metabolism, thermoregulation and reproduction) comparing all adult reproductive states reveal that male harbor porpoises have the lowest total energetic costs while females that were simultaneously lactating and pregnant had the highest [61]. The energetic cost of lactation exceeds the costs of pregnancy [61] and lactation and post-partum pregnancies require increased food intake [61,62]. In bioenergetic models, pregnant and lactating females had the highest biomass intake per day needed $(4.1 \pm 1.6 \mathrm{~kg}$, feeding on energy rich species like northern anchovy and rockfish) to travel $68.45 \pm 26.45 \mathrm{~km} /$ day [61]. 
To obtain those $4.1 \mathrm{~kg}$, a pregnant and lactating harbor porpoise would need to expend energy to capture and consume approximately 456 northern anchovies (average $9 \mathrm{~g}$ each), or one American shad (up to $5.5 \mathrm{~kg}$ ). In contrast, a male (needing $1.7 \pm 0.6 \mathrm{~kg}$ per day) would only have to capture and consume approximately 189 northern anchovies, while an American shad could be as much as 3-fold the amount of mass needed daily. Note that these estimates are based on mass alone, and do not take into consideration the differences in energy density of the prey species, which may vary. Regardless, it is clear that reproductively active females need to take in a greater mass of high quality fish than do other age/sex classes.

Reproductively active female harbor porpoises may have altered foraging behaviors compared to other sex/age classes in order to meet these increased energetic needs. They may increase foraging time, consume more prey items, ingest different prey species not seen in other harbor porpoises, and/or select prey of much larger than average length and mass [14,62-64]. Females with calves have been shown to utilize habitats with reduced water movement $[25,63]$ and have shown learned strategies to reduce unproductive foraging time [62,63]. These behaviors may impact what prey (and quantity) they take, along with how productive, in terms of energy balance, the foraging will be. This may be particularly important for pregnant females because those in poor body condition may reduce their energetic investment in the fetus, presumably to increase their own survivability [65]. Thus, pregnant females (which constituted $66.7 \%$ of females of known reproductive status catching large fish in the current study) may be more likely to attempt a potentially risky behavior (such as ingesting American shad) in order to gain the nutritional payoff that will help them maintain their health, and the health of the unborn calf. Many predators of different age, sex and reproductive classes will vary in their willingness to attack dangerous prey [66]. Our results are thus not surprising, as the constraints inherent in the lives of reproductively active female harbor porpoises make it more likely, if not necessary, for them to attempt capturing larger prey than other age/sex classes.

However, the relative risk is unclear, as there is evidence that harbor porpoises can successfully ingest larger prey items $[8,16,17,21,22,24,25]$. This has also been observed in asphyxiation events, as species that caused the death of the harbor porpoises have been found partially digested in the stomach (Table 1 cases 16 and 18; [36]), indicating that the species (and size) can sometimes be consumed without issue. These examples indicate that harbor porpoises are likely able to successfully take these larger prey, but may not be reflected in stranding data that tend to be biased toward compromised individuals, or in behavioral studies of harbor porpoises due to the difficulties in observing consumption of fish [25]. This could be another reason why our results may underrepresent the prevalence of this behavior.

Attempted ingestion of American shad appears to be an increasing phenomenon, as there were just four cases documented prior to 2005 and a subsequent increase after that, with $33 \%$ occurring between 2016 and 2020. This correlates with the continued increase in American shad, which have become the single largest spawning run of any local anadromous fish (over 4 million spawning adults passing Bonneville Dam in the Columbia River from 2003 to 2006), often dwarfing those of the salmon runs [51]. Increases in the population density of a particular species, or a steep decline in other, regular prey populations, may influence the prey choice of harbor porpoises. These factors have been suggested as reasons for asphyxiations in harbor porpoises [36] and long-finned pilot whales [43]. Alternatively, it could be related to increased inter- or intraspecific competition, as has been suggested for bottlenose dolphins engaging in riskier foraging behavior [55,67]. However, this could be an artifact of increased harbor porpoise presence, as it is difficult to tease apart true increases in a certain event from increased interest and observations. For example, an unusual mortality event along the Pacific Northwest in the period 2006-2007 was determined not to be an actual unusual mortality event, but rather a result of an increasing harbor porpoise population, expansion of harbor porpoise range and a more well-established stranding network [46]. The increasing frequency of the asphyxiation events documented in this study may indicate either shifts in native prey availability and/or in prey choice by a particular class of individuals (in this case reproductively active females), but more research is needed to understand the driving force for these behaviors. 


\section{Conclusions}

Our review of stranding records and necropsy findings on the U.S. West Coast revealed that American shad was responsible for the majority of harbor porpoise asphyxiations. This prey is an introduced species in this region and may pose a unique danger for harbor porpoises not adapted to deal with the challenges of this prey. The majority of cases involved pregnant or recently post-partum adult female harbor porpoises and this may reflect an attempt to consume large prey during periods of greater energetic need. The incidence of these events has increased, with 33\% occurring between 2016 and 2020, and likely reflects increasing abundance of this introduced species. It is striking that American shad has not been documented as harbor porpoise prey (and to our knowledge no asphyxiation events have been published) in the Atlantic, where the fish is native. Updated large-sample diet studies are needed for both coasts to help determine the prevalence of American shad (or other large prey items, like salmon) in the harbor porpoise diet. We recommend that future research should focus on both harbor porpoise and American shad morphology, energetics and behavior, along with comparisons of native and non-native prey abundance/distribution patterns and marine mammal stranding records from the U.S. West and East Coasts. This is critical to gain a better understanding of harbor porpoise foraging ecology and will help to elucidate the reasons for this behavior and the relative risk it carries for harbor porpoise populations.

Author Contributions: Conceptualization, C.R.E., D.N.D., D.A.D., J.L.H., J.R., I.S. and M.W.; project administration, C.R.E.; resources, D.N.D., D.A.D., J.L.H., J.R., I.S. and M.W.; supervision, C.R.E.; validation, C.R.E., J.C., D.N.D., D.A.D., J.L.H., J.R., I.S. and M.W.; visualization, C.R.E., J.C., D.N.D., J.L.H., J.R., I.S. and M.W.; writing-original draft, C.R.E.; writing - review and editing, C.R.E., J.C., D.N.D., D.A.D., J.L.H., J.R., I.S. and M.W. All authors have read and agreed to the published version of the manuscript.

Funding: Stranding response activities since 2004 were supported by several grants from the John H. Prescott Marine Mammal Rescue Assistance Grant Program (NOAA fisheries).

Acknowledgments: Thanks to all the staff, volunteers, and supporters of Pacific Mammal Research, especially S. Elliser and Marathon Petroleum Foundation. Thanks to all the staff and volunteers from Cascadia Research for assistance with response and examinations, specifically E. Keene. Thanks to former and current Seaside Aquarium staff for assisting Portland State University with stranding response, specifically K. Chandler, J. Hussa and T. Boothe. Thanks to all the staff and volunteers from The Marine Mammal Center and The California Academy of Sciences. Thanks to the efforts of the many volunteers of the Oregon Marine Mammal Stranding Network. Thanks to S. Sveegaard for the personal communication, W. Keener and C. Gallagher for reviews of the manuscript, D. Anderson for assistance in creating the map, D. Lowry from WDFW for shark and fish identification, M. Myrsell from the Westport Aquarium for assistance with carcass recovery and examination of one case and D. Lambourn from Washington Department of Fish and Wildlife for details on the case from their historical records that all improved the manuscript. We appreciate the suggestions of two anonymous reviewers that improved the manuscript.

Conflicts of Interest: The authors declare no conflict of interest.

\section{References}

1. Osmek, S.; Calambokidis, J.; Laake, J.; Gearin, P.; Delong, R.; Scordino, J.; Jeffries, S.; Brown, R. Assessment of the Status of Harbor Porpoise (Phocoena phocoena) in Oregon and Washington Waters; NOAA Technical Memorandum NMFS-AFSC-76; U.S. Department of Commerce: Washington, DC, USA, 1996.

2. Barlow, J. Harbor porpoise, Phocoena phocoena, abundance estimation for California, Oregon, and Washington I. Ship surveys. Fish. Bull. 1988, 83, 417-432.

3. Forney, K.A.; Carretta, J.V.; Benson, S.R. Preliminary Estimates of Harbor Porpoise Abundance in Pacific Coast Waters of California, Oregon, and Washington, 2007-2012; NOAA Technical Memorandum NMFS-SWFSC-537; U.S. Department of Commerce: Washington, DC, USA, 2014.

4. Encyclopedia Britannica. Available online: https://www.britannica.com/science/continental-shelf (accessed on 1 June 2020).

5. Nielsen, N.H.; Teilmann, J.; Sveegaard, S.; Hansen, R.G.; Sinding, M.H.S.; Dietz, R.; Heide-Jørgensen, M.P. Oceanic movements, site fidelity and deep diving in harbour porpoises from Greenland show limited similarities to animals from the North Sea. Mar Ecol. Prog. Ser. 2018, 597, 259-272. [CrossRef] 
6. Jones, R.E. Food habits of smaller marine mammals from northern California. Proc. Calif. Acad. Sci. 1981, 42, 409-433.

7. Dorfman, E.J. Distribution, Behavior, and Food Habits of Harbor Porpoises (Phocoena phocoena) in Monterey Bay. Master's Thesis, San Jose State University, San Jose, CA, USA, 1990.

8. Gearin, P.J.; Melin, S.R.; Delong, R.L.; Kajimura, H.; Johnson, M.A. Harbor porpoise interactions with a chinook salmon set-net fishery in Washington State. Rep. Int. Whal. Commn. Special 1994, 427-438.

9. Walker, W.A.; Hanson, M.B.; Baird, R.W.; Guenther, T.J. Food habits of the harbor porpoise, Phocoena phocoena, and Dall's porpoise, Phocoenoides dalli, in the inland waters of British Columbia and Washington. Alask. Fish. Sci. Center Process. Rep. 1998, 98-10, 63-75.

10. Toperoff, A.K. Examination of Diet of Harbor Porpoise (Phocoena phocoena) from Central California Using Stomach Content and Stable Isotope Analysis from Multiple Tissues. Master's Thesis, San Jose State University, San Jose, CA, USA, 2002.

11. Nichol, L.M.; Hall, A.M.; Ellis, G.M.; Stredulinsky, E.; Boogaards, M.; Ford, J.K. Dietary overlap and niche partitioning of sympatric harbour porpoises and Dall's porpoises in the Salish Sea. Prog. Oceanogr. 2013, 115, 202-210. [CrossRef]

12. Oliaro, J.F. Identification of Harbor Porpoise (Phocoena phocoena) Prey Species Using PCR Based Molecular Technique. Master's Thesis, San Francisco University, San Francisco, CA, USA, 2013.

13. Smith, G.J.D.; Gaskin, D.E. The diet of harbor porpoises (Phocoena phocoena (L.)) in coastal water of Eastern Canada, with special reference to the Bay of Fundy. Can. J. Zool. 1974, 52, 777-782. [CrossRef]

14. Recchia, C.A.; Read, A.J. Stomach contents of harbour porpoises, Phocoena phocoena (L.), from the Bay of Fundy. Can. J. Zool. 1989, 67, 2140-2146. [CrossRef]

15. Smith, R.J.; Read, A.J. Consumption of euphausiids by harbour porpoise (Phocoena phocoena) calves in the Bay of Fundy. Can. J. Zool. 1992, 70, 1629-1632. [CrossRef]

16. Fontaine, P.M.; Hammill, M.O.; Barrette, C.; Kingsley, M.C. Summer diet of the harbour porpoise (Phocoena phocoena) in the estuary and the northern Gulf of St. Lawrence. Can. J. Fish. 1994, 51, 172-178. [CrossRef]

17. Aarefjord, H.; Bjørge, A.J.; Kinze, C.C.; Lindstedt, I. Diet of the harbour porpoise (Phocoena phocoena) in Scandinavian waters. Oceanogr. Lit. Rev. 1996, 10, 1041.

18. Martin, A.R. The Diet of Harbour Porpoises (Phocoena phocoena) in British Waters; SC/47/SM48; International Whaling Commission: Cambridge, UK, 1996.

19. Benke, H.; Siebert, U.; Lick, R.; Bandomir, B.; Weiss, R. The current status of harbor porpoises (Phocoena phocoena) in German waters. Arch. Fish. Mar. Res./Arch. Fisch. Meeresforsch. 1998, 46, 97-123.

20. Gannon, D.P.; Craddock, J.E.; Read, A.J. Autumn food habits of harbor porpoises, Phocoena phocoena, in the Gulf of Maine. Fish. Bull. 1998, 96, 428-437.

21. Víkingsson, G.A.; Ólafsdóttir, D.; Sigurjónsson, J. Geographical, and seasonal variation in the diet of harbour porpoises (Phocoena phocoena) in Icelandic coastal waters. NAMMCO Sci. Publ. 2003, 5, 243-270. [CrossRef]

22. Sveegaard, S.; Andreasen, H.; Mouritsen, K.N.; Jeppesen, J.P.; Teilmann, J.; Kinze, C.C. Correlation between the seasonal distribution of harbour porpoises and their prey in the Sound, Baltic Sea. Mar. Biol. 2012, 159, 1029-1037. [CrossRef]

23. Wisniewska, D.M.; Johnson, M.; Teilmann, J.; Rojano-Doñate, L.; Shearer, J.; Sveegaard, S.; Madsen, P.T. Ultra-high foraging rates of harbor porpoises make them vulnerable to anthropogenic disturbance. Curr. Biol. 2016, 26, 1441-1446. [CrossRef] [PubMed]

24. Andreasen, H.; Ross, S.D.; Siebert, U.; Andersen, N.G.; Ronnenberg, K.; Gilles, A. Diet composition and food consumption rate of harbor porpoises (Phocoena phocoena) in the western Baltic Sea. Mar. Mammal Sci. 2017, 33, 1053-1079. [CrossRef]

25. Elliser, C.R.; Hessing, S.; MacIver, K.H.; Webber, M.A.; Keener, W. Harbor porpoises (Phocoena phocoena vomerina) catching and handling large fish on the U.S. West Coast. Aquat. Mamm. 2020, 46, 191-199. [CrossRef]

26. D'Alessandro, D.N.; Duffield, D.A. Salmonid passive integrated transponder tags and coded wire tags found in the forestomach of a harbor porpoise (Phocoena phocoena) in southwestern Washington. Fish. Bull. 2019, 117, 303-307. [CrossRef] 
27. Treacy, S.D. Feeding habits of marine mammals from Grays Harbor, Washington to Netarts Bay Oregon. Marine mammals and their interactions with fisheries of the Columbia River and adjacent waters, 1980-1982. NOAA: Northwest Alaska Fish. Sci. Cent. NWAFC Processed Report 85-04. Natl. Mar. Fish. Serv. 1985, 149-198. Available online: https://archive.fisheries.noaa.gov/afsc/Publications/ProcRpt/NWAFCPR85-04.pdf (accessed on 2 May 2020).

28. Orr, R.T. A porpoise chokes on a shark. J. Mammal. 1937, 18, 370. [CrossRef]

29. Hult, R.W.; Dupey, S.E.; Badley, R.W. Mortalities associated with prey ingestion by small cetaceans. Cetology 1980, 38, 1-2.

30. Scheffer, V.B.; Slipp, J.W. The whales and dolphins of Washington State with a key to the cetaceans of the West Coast of North America. Am. Midl. Nat. 1948, 39, 257-337. [CrossRef]

31. Scheffer, V.B. Measurements and stomach contents of eleven delphinids from Northeast Pacific. Murrelet 1953, 34, 27-30. [CrossRef]

32. Wilkin, S.M.; Cordaro, J.; Gulland, F.M.D.; Wheeler, E.; Dunkin, R.; Sigler, T.; Casper, D.; Berman, M.; Flannery, M.; Fire, S.; et al. An unusual mortality event of harbor porpoises (Phocoena phocoena) off central California: Increase in blunt trauma rather than an epizootic. Aquat. Mamm. 2012, 38, 301-310. [CrossRef]

33. MacLeod, C.D.; Reidenberg, J.S.; Weller, M.; Santos, M.B.; Herman, J.; Goold, J.; Pierce, G.J. Breaking symmetry: The marine environment, prey size, and the evolution of asymmetry in cetacean skulls. Anat. Rec. 2007, 290, 539-545. [CrossRef] [PubMed]

34. Siebert, U.; Wünschmann, A.; Weiss, R.; Frank, H.; Benke, H.; Frese, K. Post-mortem findings in harbour porpoises (Phocoena phocoena) from the German North and Baltic Seas. J. Comp. Path. 2001, 124, 102-114. [CrossRef] [PubMed]

35. Ryan, C.; Bolin, V. Stranded harbour porpoise (Phocoena phocoena (Grey)) with throat obstructed by a scad (Trachurus trachurus (L.)). Ir. Nat. J. 2014, 33, 155.

36. Roller, M.; Gross, S.; Reckendorf, A.; Andreasen, H.; Wohlsein, P.; Siebert, U. Fatal asphyxiation with laryngeal displacement caused by platvissen in harbour porpoises. In Proceedings of the 31st Annual Conference of the European Cetacean Society, Middelfart, Denmark, 1-3 May 2017.

37. Sveegaard, S. Personal Communication; Aarhus University: Aarhus, Denmark, 2020.

38. Byard, R.W.; Gilbert, J.D.; Gibbs, S.E.; Kemper, C.M. Cetacean Café Coronary. J. Clin. Forensic Med. 2003, 10, 85-88. [CrossRef]

39. Byard, R.W.; Tomo, I.; Kemper, C.M.; Gibbs, S.E.; Bossley, M.; Machado, A.; Hill, M. Unusual causes of fatal upper aerodigestive tract obstruction in wild bottlenose dolphins (Tursiops aduncus). Forensic Sci. Med. Pathol. 2010, 6, 207-210. [CrossRef]

40. Watson, A.; Gee, L.E. Laryngeal displacement and asphyxiation by a beheaded sheepshead (Archosargus probatocephalus) in a bottlenose dolphin (Tursiops truncatus). Aquat. Mamm. 2005, 31, 447-452. [CrossRef]

41. Mignucci-Giannoni, A.A.; Rosario-Delestre, R.J.; Alsina-Guerrero, M.M.; Falcon-Matos, L.; Guzmán-Ramírez, L.; Williams, E.H.; Bossart, G.D.; Reidenberg, J. Asphyxiation in a bottlenose dolphin (Tursiops truncatus) from Puerto Rico due to choking on a black margate (Anisotremus surinamensis). Aquat. Mamm. 2009, 35, 48-54. [CrossRef]

42. Stolen, M.; St. Leger, S.; Noke Durden, W.; Mazza, T.; Nilson, E. Fatal asphyxiation in bottlenose dolphins (Tursiops trunactus) from the Indian River Lagoon. PLoS ONE 2013, 8, e66828. [CrossRef] [PubMed]

43. IJsseldijk, L.L.; Leopold, M.F.; Bravo Rebolledo, E.L.; Deaville, R.; Haelters, J.; IJzer, J.; Jepson, P.D.; Gröne, A. Fatal asphyxiation in two long-finned pilot whales (Globicephala melas) caused by common soles (Solea solea). PLoS ONE 2015, 10, e0141951. [CrossRef] [PubMed]

44. Mariani, D.B.; Guimarães, J.P.; Batista, R.G.; Brum, A.; Groch, K.R.; Díaz-Delgado, J.; Parente, J.E.V. Fatal asphyxia due to laryngeal displacement by large-sized prey in a Guiana dolphin (Sotalia guianensis), Brazil. Cienc. Rural 2020, 50, e20190068. [CrossRef]

45. Rouse, N.; Burek-Huntington, K.A.; Shelden, K.E.W. Asphyxiation of an endangered Cook Inlet beluga whale, Delphinapterus leucas. Mar. Fish. Rev. 2017, 79, 38-43. [CrossRef]

46. Huggins, J.L.; Raverty, S.A.; Norman, S.A.; Calambokidis, J.; Gaydos, J.K.; Duffield, D.A.; Lambourn, D.M.; Rice, J.M.; Hanson, B.; Wilkinson, K.; et al. Increased harbor porpoise mortality in the Pacific Northwest, USA: Understanding when higher levels may be normal. Dis. Aquat. Organ. 2015, 115, 93-102. [CrossRef]

47. Pearcy, W.G.; Fisher, P. Ocean distribution of the American shad (Alosa sapidissma) along the Pacific coast of North America. Fish. Bull. 2011, 109, 440-453. 
48. Pugliares-Bonner, K.; Bogomolni, A.; Touhey, K.; Herzig, S.; Harry, C.; Moore, M. Marine Mammal Necropsy: An Introductory Guide for Stranding Responders and Field Biologists. Woods Hole Oceanog. Inst. Tech. Rept. 2007. [CrossRef]

49. Williams, R.; Gero, S.; Bejder, L.; Calambokidis, J.; Kraus, S.D.; Lusseau, D.; Read, A.J.; Robbins, J. Underestimating the damage: Interpreting cetacean carcass recoveries in the context of the Deepwater Horizon/BP incident. Conserv. Lett. 2011, 4, 228-233. [CrossRef]

50. Moore, M.J.; Mitchell, G.H.; Rowles, T.K.; Early, G. Dead cetacean? Beach, bloat, float, sink. Front. Mar. Sci. 2020, 7, 333. [CrossRef]

51. Hasselman, D.J.; Hinrichsen, R.A.; Shields, B.A.; Ebbesmeyer, C.C. The rapid establishment, dispersal and increased abundance of invasive American shad in the Pacific Northwest. Fisheries 2012, 37, 103-114. [CrossRef]

52. U.S. Fish and Wildlife Service. Available online: https://www.fws.gov/fisheries/freshwater-fish-of-america/ american_shad.html (accessed on 1 June 2020).

53. Lodi, L.; Hetzel, B. Rough-toothed dolphin, Steno bredanensis, feeding behavior in Ilha Grande Bay, Brazil. Biociéncias 1999, 7, 29-42.

54. Best, R.C.; da Silva, V.M.F. Inia geoffrensis de Blainville, 1817. Mamm. Species 1993, 426, 1-8.

55. Ronje, E.I.; Barry, K.P.; Sinclair, C.; Grace, M.A.; Barros, N.; Allen, J.; Balmer, B.; Panike, A.; Toms, C.; Mullin, K.D.; et al. A common bottlenose dolphin (Tursiops truncatus) prey handling technique for marine catfish (Ariidae) in the northern Gulf of Mexico. PLoS ONE 2017, 12, e0181179. [CrossRef]

56. Ralls, K.; Mesnick, S.L. Sexual dimorphism. In Encyclopedia of Marine Mammals; Perrin, W.F., Wursig, B., Thewissen, J.G.M., Eds.; Academic Press: San Diego, CA, USA, 2002; pp. 1071-1078.

57. Hohn, A.A.; Brownell, J.R.L., Jr. Harbor Porpoise in Central California Waters: Life History and Incidental Catches; IWC Report SC/42/SM47; International Whaling Commission: Cambridge, UK, 1990.

58. Norman, S.A.; Hanson, M.B.; Huggins, J.; Lambourn, D.; Calambokidis, J.; Cottrell, P.; Greene, A.; Raverty, S.; Berta, S.; Dubpernell, S.; et al. Conception, fetal growth, and calving seasonality of harbor porpoise (Phocoena phocoena) in the Salish Sea waters of Washington, USA and southern British Columbia, Canada. Can. J. Zool. 2018, 96, 566-575. [CrossRef]

59. Read, A.J.; Hohn, A.A. Life in the fast lane: The life history of harbor porpoises from the Gulf of Maine. Mar. Mammal Sci. 1995, 11, 423-440. [CrossRef]

60. Lockyer, C.; Kinze, C. Status, ecology and life history of harbour porpoise (Phocoena phocoena), in Danish waters. NAMMCO Sci. Publ. 2003, 5, 143-175. [CrossRef]

61. Gallagher, C.A.; Stern, S.J.; Hines, E. The metabolic cost of swimming and reproduction in harbor porpoises (Phocoena phocoena) as predicted by a bioenergetic model. Mar. Mammal Sci. 2018, 34, 875-900. [CrossRef]

62. Yasui, W.Y.; Gaskin, D.E. Energy budget of a small cetacean, the harbour porpoise, Phocoena phocoena (L.). Ophelia 1986, 25, 183-197. [CrossRef]

63. Gaskin, D.E.; Watson, A.P. The harbor porpoise, Phocoena phocoena, in Fish Harbour, New Brunswick, Canada: Occupancy, distribution, and movements. Fish. Bull. 1985, 83, 427-442.

64. Smith, G.J.D.; Gaskin, D.E. An environmental index for habitat utilization by female harbour porpoises with calves near Deer Island, Bay of Fundy. Ophelia 1983, 22, 1-13. [CrossRef]

65. Christiansen, F.; Víkingsson, G.A.; Rasmussen, M.H.; Lusseau, D. Female body condition affects foetal growth in a capital breeding mysticete. Funct. Ecol. 2014, 28, 579-588. [CrossRef]

66. Mukherjee, S.; Heithaus, M.R. Dangerous prey and daring predators: A review. Biol. Rev. 2013, 88, 550-563. [CrossRef] [PubMed]

67. McGovern, B.; Gridley, T.; James, B.S.; Elwen, S. Risky business? A note on repeated live strandings of common bottlenose dolphins (Tursiops truncatus) while foraging in a shallow water environment. Mar. Mammal Sci. 2019, 36, 305-314. [CrossRef]

(C) 2020 by the authors. Licensee MDPI, Basel, Switzerland. This article is an open access article distributed under the terms and conditions of the Creative Commons Attribution (CC BY) license (http://creativecommons.org/licenses/by/4.0/). 